\title{
Enterically Transmitted Non-A, Non-B Hepatitis and the Discovery of Hepatitis E Virus
}

\author{
Stanley M. Lemon ${ }^{1}$ and Christopher M. Walker ${ }^{2}$ \\ ${ }^{1}$ Departments of Medicine and Microbiology \& Immunology, Lineberger Comprehensive Cancer Center; \\ The University of North Carolina at Chapel Hill, Chapel Hill, North Carolina 27599-7292 \\ ${ }^{2}$ Center for Vaccines and Immunity, The Research Institute at Nationwide Children's Hospital and College \\ of Medicine, The Ohio State University, Columbus, Ohio 43205 \\ Correspondence: smlemon@med.unc.edu
}

The recognition of hepatitis $\mathrm{E}$ as a discreet disease entity in the late 1970s followed the development of serological tests for hepatitis $\mathrm{A}$ and the discovery that large waterborne outbreaks of hepatitis in India were not caused by hepatitis A virus (HAV). These "enterically transmitted non-A, non-B hepatitis" outbreaks had distinctive epidemiologic features, including the highest attack rates among young adults, little secondary household transmission of infection, and severe disease in pregnant women. The responsible agent, hepatitis $\mathrm{E}$ virus $(\mathrm{HEV})$, was identified several years later in extracts of feces from a self-inoculated virologist. Multiple genetically related HEV genotypes are now known to exist, two of which are common in domestic swine herds and the cause of sporadic cases of acute hepatitis in economically well-developed countries. HEV genotypes possess impressive genetic and biologic diversity, and present many unanswered questions concerning their natural host range, potential for zoonotic transmission, and disease pathogenesis.

In many ways, hepatitis E virus (HEV) is the most enigmatic and least well understood of the five hepatotropic viruses that cause acute hepatitis in humans. It is certainly the least well studied. The earliest recorded outbreak of epidemic jaundice likely caused by HEV occurred in St. Pierre on the island of Martinique in the late spring and summer of 1858 and was described by O. Saint-Vel in the Gazette des Hôpitaux in 1862 (Anonymous 1863). Most cases of jaundice occurred in adults, and 20 of 30 affected pregnant women succumbed to the disease in coma after aborting or delivering prematurely between the fourth and eighth months of pregnancy. No deaths were recorded among men. Hemorrhage was uncommon, and the disease was not considered to resemble yellow fever. The age distribution of the cases, with most among adults, and the high mortality rate among pregnant women typify outbreaks of hepatitis E and suggest that the 1858 Martinique outbreak was likely caused by $\mathrm{HEV}$, not hepatitis A virus (HAV).

Definitive recognition of the existence of two types of enterically transmitted infectious hepatitis came only after the discovery of HAV by Stephen M. Feinstone and colleagues at the U.S. National Institutes of Health, which al-

Editors: Stanley M. Lemon and Christopher Walker

Additional Perspectives on Enteric Hepatitis Viruses available at www.perspectivesinmedicine.org

Copyright (C) 2019 Cold Spring Harbor Laboratory Press; all rights reserved; doi: 10.1101/cshperspect.a033449

Cite this article as Cold Spring Harb Perspect Med 2019;9:a033449 
lowed development of specific serologic assays for anti-HAV antibodies (see Feinstone et al. 1973; Feinstone 2018). Subsequent studies showed that an antigenically distinct infectious agent was responsible for outbreaks of hepatitis related to contaminated water in India (Khuroo 1980b). Soon thereafter, the virus was identified using methods very similar to those used to identify HAV (Balayan et al. 1983). The discovery of HEV was thus intimately linked to the discovery of HAV that preceded it by a decade. Molecular cloning of the HEV genome followed a few years later (Reyes et al. 1990), leading eventually to the recognition of HEV genotypes, potential zoonotic transmission of the virus, and genotype-specific distinctions in the epidemiology and clinical course of HEV infection.

Once considered limited to economically underdeveloped regions with poor sanitation, HEV infections are now known to be prevalent in many well-developed nations (Bendall et al. 2010). Our understanding of the clinical consequences of HEV infection also continues to broaden. Typically clinically silent in otherwise healthy individuals, genotype (gt) $3 \mathrm{HEV}$ infections can persist and lead to chronic hepatitis with significant hepatic fibrosis in persons with compromised immunity (Kamar et al. 2008). Potential extrahepatic manifestations of HEV infection, including in particular Guillain-Barré syndrome and peripheral nerve palsies, are also gaining increasing attention (Pischke et al. 2017).

\section{ENTERICALLY TRANSMITTED NON-A, NON-B HEPATITIS}

The discovery of Australia antigen and its association with hepatitis B virus (HBV) (Blumberg et al. 1965; Prince 1968), followed a few years later by the discovery of HAV particles in the feces of an experimentally infected human subject (Feinstone et al. 1973), led to the development of specific serologic assays for the two types of viral hepatitis then known to exist. These developments ushered in a golden age of research on viral hepatitis, and a concerted quest for additional hepatotropic viruses capable of causing hepatitis in humans. Most patients developing acute hepatitis following blood transfusion were found to lack serologic markers of either $\mathrm{HAV}$ or HBV infection, leading to recognition of what became known as parenterally transmitted non-A, non-B hepatitis (PT-NANB), now hepatitis C (Feinstone et al. 1975). The search was on then for a fourth hepatitis virus, prompted in part by reports of multiple bouts of hepatitis in some patients that could not be related to either HAV or HBV (Mosley et al. 1977).

In 1975, Victor M. Villarejos, an epidemiologist working at an overseas training and research site of the Louisiana State University in San Jose, Costa Rica, described a series of 103 patients with acute viral hepatitis (Villarejos et al. 1975). State-of-the-art serological tests provided by Phillip Provost and Maurice Hilleman at the Merck Institute for Therapeutic Research identified HAV or HBV infection in 91 of these cases, leaving in question the cause of hepatitis in the remaining 12 subjects. These 12 subjects ranged in age from 2 to 54 years of age, with a median age of 10 years. Six of the affected individuals were from one town, and four were members of a single family, suggesting the possibility of household transmission of an infectious agent (Villarejos et al. 1975). None had been transfused recently, distinguishing them from the subjects with non- $A$, non-B hepatitis reported that same year by Feinstone and colleagues (1975). The disease was relatively mild in the patients described by Villarejos: only three were icteric, and six were described as "subclinical" with serum alanine aminotransferase (ALT) elevations ranging up to $345 \mathrm{U} / \mathrm{mL}$. Serum enzyme elevations did not persist for more than several weeks. Nine of the 12 subjects studied by Villarejos had preexisting antibodies to $\mathrm{HAV}$, and none showed increases in anti-HAV titer in follow-up tests. Tests for infectious mononucleosis were negative, and cytomegalovirus infection was excluded by serological testing in all but one of the 12 subjects. Villarejos and colleagues (1975) concluded that the hepatitis observed in these Costa Rican subjects was likely caused by a previously unrecognized human hepatitis virus.

Definitive evidence for an enterically transmitted non-A, non-B (ET-NANB) hepatitis 
The Discovery of Hepatitis E Virus

agent followed a few years later. Mohammad S. Khuroo, a young gastroenterologist who had just completed his subspecialty training at the Institute of Medical Education \& Research at Chandigarh, described a large, waterborne outbreak of hepatitis during the winter of 19781979 in the Baramulla district of the Kashmir valley, a remote, mountainous region in the north of India (Fig. 1) (Khuroo 1980b). Khuroo collected clinical and epidemiologic data from 269 cases of hepatitis occurring among 12,900 inhabitants of 11 small villages in which drinking water was obtained from the Ningli Nallah, a mountain stream that joins the Jhelum River close to Sopore and eventually flows into the Indus River. In contrast, only six cases of hepatitis were identified among 3720 inhabitants of four neighboring villages with alternative water supplies, strongly incriminating contaminated water as the source of the outbreak. Afflicted patients ranged in age from $<10$ to 60 years of age, with the highest attack rate in those 21-30 years old and an approximately equal sex distribution. The majority of affected patients were icteric, with serum bilirubin ranging from 2 to 22.2 (mean 5.98) $\mathrm{mg} / \mathrm{dL}$ and serum ALT from 97 to 297 (mean 122) IU/L (Khuroo 1980b). Cholestatic symptoms (clay-colored stools and pruritis) were prominent in a fifth of the patients. Symptoms typically resolved within a week or two of the onset of jaundice, but 12 patients $(4.5 \%)$ progressed to fulminant hepatic failure with encephalopathy; 10 died, including six women in the third trimester of pregnancy (Khuroo 1980b). Thirty-three of 35 patients who were tested serologically were found to be anti-HAV positive (136 of 141 in a subsequent, expanded serological survey) (Khuroo 1980b), but only one had immunoglobulin (Ig)M antiHAV indicative of recent or current infection. None had serum markers of HBV infection.

Liver biopsies from patients involved in the Kashmir outbreak showed histologic changes consistent with severe viral hepatitis, including portal inflammatory infiltrates with ballooning degeneration and bridging necrosis of hepatocytes (Khuroo 1980b). Canalicular bile stasis and gland-like clusters of hepatocytes ("rosettes") were prominent in some biopsies, whereas submassive hepatic necrosis was observed postmortem in a patient with fulminant disease. In contrast to posttransfusion PT-NANB hepatitis, follow-up biopsies performed several months later revealed resolution of the histologic abnormalities and suggested a very low risk, if any, of progression to chronicity (Khuroo 1980a).

In addition to the lack of IgM anti-HAV, the age distribution of cases in the Kashmir outbreak was recognized to be very unusual for

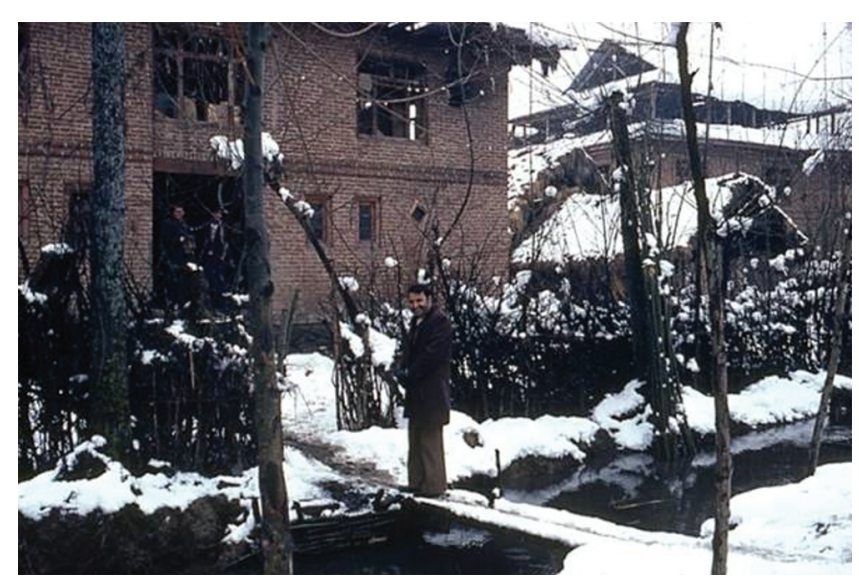

Figure 1. Mohammed Khuroo standing near an open source of drinking water in Sopore, at the time of the 19781979 winter outbreak of enterically transmitted non-A, non-B (ET-NANB) he investigated in Kashmir. (From Khuroo 2011; adapted, with permission, from Elsevier (C) 2011.) 
hepatitis $\mathrm{A}$ in a region where HAV was highly endemic and most children were seropositive by the age of 5 . Several other clinical and epidemiologic features of the outbreak were also recognized to distinguish it from hepatitis A. Most striking was the high mortality rate observed in pregnant women with hepatitis, which had been noted previously among women with sporadic hepatitis in Kashmir, but never explained (Khuroo et al. 1981; Khuroo 2011). A subsequent study revealed that the risk of symptomatic hepatitis increased as pregnancy progressed, being highest in the third trimester, and that as many as $22 \%$ of affected pregnant women developed fulminant hepatitis (Khuroo et al. 1981). A low frequency of secondary transmission within households was also considered atypical for hepatitis A, as was the degree of cholestasis and rosetting of hepatocytes noted in liver biopsies (Khuroo 1980b).

Similar histologic findings had been described in a large outbreak of hepatitis involving about 29,000 cases of frank jaundice that occurred in Delhi in 1955-1956 (Gupta and Smetana 1955; Khuroo 1980b). Similar to the disease in Kashmir, a high mortality rate $(\sim 10.5 \%)$ had been noted among pregnant women involved in the Delhi outbreak (Wong et al. 1980). The Delhi epidemic had been linked to sewage contaminating the city water supply, as was the case with another outbreak of hepatitis involving 2600 cases in Ahmedabad in 1975-1976. A collaborative study led by Khorshed $\mathrm{M}$. Pavri at the National Institute of Virology in Pune and Robert H. Purcell of the U.S. National Institutes of Health retrospectively examined acute and convalescent serum samples collected from subsets of persons involved in both outbreaks, and found no evidence of either acute HAV or $\mathrm{HBV}$ infection in most of the subjects tested
(Wong et al. 1980). Sera were also tested from 22 patients with sporadic, apparently endemic hepatitis occurring in Pune, in West-Central India. Similar to those in the Delhi and Ahmedabad outbreaks, these patients lacked serologic evidence of recent $\mathrm{HAV}$ or $\mathrm{HBV}$ infection. As in Kashmir, the vast majority of the hepatitis patients in Delhi, Ahmedabad, and Pune had preexisting antibodies to HAV, but few had IgM anti-HAV or showed significant increases in anti-HAV titer in convalescent serum samples (Wong et al. 1980).

The dual 1980 reports by Khuroo (1980b) and Wong et al. (1980) firmly established the widespread existence in India of epidemic ETNANB hepatitis with clinical and epidemiologic features distinct from both hepatitis A and posttransfusion PT-NANB. Subsequent studies performed in Gujarat state, $2000 \mathrm{~km}$ distant from Kashmir on the northwest coast of India and bordering the Arabian Sea, confirmed ETNANB to be the most prevalent form of acute sporadic hepatitis and the most likely cause of subacute hepatitis progressing to hepatic failure (Table 1) (Tandon et al. 1985). HAV was highly endemic in India during this period. Unlike ETNANB, however, most HAV infections were contracted early in life, and not associated with clinically evident hepatitis.

\section{IDENTIFICATION OF HEPATITIS E VIRUS}

$\mathrm{HEV}$, the virus responsible for ET-NANB and the first member of the Hepeviridae virus family, was identified by a Russian virologist, Mikhail S. Balayan (Fig. 2) in late 1981 (Balayan et al. 1983). Balayan was Deputy Director of the Institute of Poliomyelitis and Viral Encephalitis of the Academy of Medical Sciences of the USSR (now the Chumakov Institute of Poliomyelitis

Table 1. Viral etiology of acute hepatitis: Gujarat, India, 1985

\begin{tabular}{lcccc}
\hline & $n$ & Hepatitis A & Hepatitis B & Non-A, non-B hepatitis \\
\hline Acute sporadic hepatitis & 362 & $16 \%$ & $26 \%$ & $58 \%$ \\
Fulminant hepatitis $^{\text {Subacute hepatitis }}{ }^{\mathrm{a}}$ & 130 & $15 \%$ & $27 \%$ & $58 \%$ \\
Epidemic hepatitis & 56 & $4 \%$ & $9 \%$ & $87 \%$ \\
\hline
\end{tabular}

${ }^{\mathrm{a}}$ Delayed progression to liver failure. (Data from Tandon et al. 1985, courtesy of the World Health Organization.) 


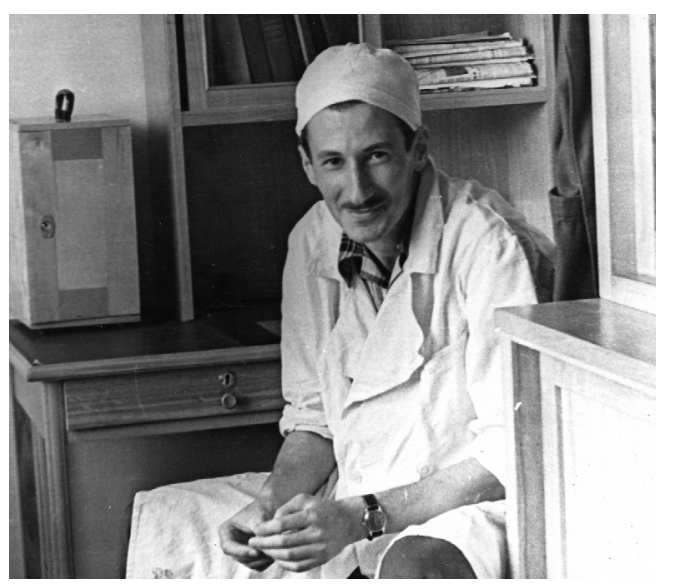

Figure 2. An undated photograph of Mikhail S. Balayan, the Russian virologist who first identified hepatitis E virus (HEV) particles in extracts of his stool following ingestion of a fecal extract prepared from Soviet soldiers afflicted with enterically transmitted non-A, non-B (ET-NANB). (Image provided by M. Mikhailov.)

and Viral Encephalitides) in Moscow, and at the time was head of the hepatitis laboratory within the Institute. He had previously been a graduate student and later a research associate in the laboratory of Marina K. Voroshilova, with whom he had studied poliovirus at the Institute. In the late 1960s, he served as a consultant virologist at the National Institute of Hygiene, Epidemiology and Microbiology, in Havana, Cuba, and from 1971 to 1976 he had worked with a World Health Organization-sponsored project in Uganda (M Mikhailov, pers. comm.).

Balayan's discovery of HEV occurred against the backdrop of extensive outbreaks of hepatitis among Russian soldiers in Afghanistan. The Soviet Union had deployed military forces to Afghanistan in December 1979, in an effort to prop up a faltering government established several years earlier by the communist People's Democratic Party of Afghanistan. The guerilla war that ensued with the Afghan mujahideen was brutal and long, lasting for 9 years until the withdrawal of Soviet troops in February 1989. Medical casualties were high. Of the 640,000 Soviet troops who served in Afghanistan during the war, 416,000 were hospitalized for disease, of whom 115,000 were hospitalized for hepatitis (Grau and Jorgensen 1995). Hepatitis was a constant threat, plaguing the Soviet troops throughout their deployment because of poor field sanitation and inadequate clean water supplies. At one point, in 1981, an entire motorized rifle division was rendered combat ineffective when one quarter of its strength (over 3000 men, including the commander) was ill with hepatitis (Grau and Jorgensen 1995). The Soviet troops were immunized against hepatitis $B$, and $95 \%$ of the cases were considered to be hepatitis A according to a 1991 review by V.S. Peripelkin and colleagues in a Soviet military medicine journal (Perepelkin et al. 1991; Grau and Jorgensen 1995). This seems unlikely, however, given that the seroprevalence of anti-HAV antibodies was probably quite high among the Soviet troops. As many as $73 \%-88 \%$ of 15 - to 20 -year-old Russians living in the lower Volga region were reported to be anti-HAV positive in 1987 (Prikazchikov and Balayan 1987). The incubation period for hepatitis among the Soviet troops was also reported to be 37 days (Grau and Jorgensen 1995), which is arguably closer to that for ET-NANB than hepatitis A. Consistent with this, sera collected in 1980 from jaundiced Soviet military personnel in the northeastern part of Afghanistan, along the border with Tajikistan where hepatitis rates were particularly high, showed no markers of acute hepatitis A or hepatitis B when tested in Moscow using radioimmunoassays from Abbott Laboratories in the United States (M Favorov, pers. comm.).

In August of 1981, Balayan, together with two members of his laboratory, Alexander Anjaparidze and Svetlana Savinskaya, investigated an outbreak of hepatitis occurring among soldiers in a military camp in Afghanistan. Sera and stool were collected within several days of the onset of symptoms from 22 affected individuals, 15 of whom had a history of having had hepatitis A in February of 1981 (Andjaparidze 2010). All of these patients had tested negative for HBV surface antigen (HBsAg), and were considered to have nonparenterally transmitted ET-NANB hepatitis similar to that described by Khuroo (1980b). Fecal samples collected from the Soviet soldiers were taken to a military base in Tashkent, Uzbekistan, where Balayan (who 
had antibodies to HAV from prior exposure) famously infected himself by ingesting an extract of the material. His rationale, when questioned subsequently, was that this was the most expeditious way to determine whether the outbreak was caused by an unknown virus that was antigenically distinct from HAV (M Mikhailov, pers. comm.). A concentrated inoculum was prepared from clarified and filtered extracts of feces collected from nine patients 1 to 4 days after the onset of jaundice (Balayan et al. 1983). The inoculum was mixed with kefir (a fermented milk drink originating in the Caucasus) and ingested by Balayan. Other than his coworkers, Andjaparidze and Savinskaya, only the Poliomyelitis Institute director, Sergei Drozdov, was aware of the experiment (M Mikhailov, pers. comm.).

Upon his return to Moscow, 36 days after ingesting the inoculum, Balayan became acutely ill with symptoms and signs of viral hepatitis, including anorexia, nausea, vomiting, abdominal pain, dark urine, frank jaundice, hepatomegaly, and ALT elevations to $3010 \mathrm{IU} / \mathrm{L}$ (Balayan et al. 1983). He was admitted to the First Infectious Diseases Hospital in Moscow in the middle of the night in a moderately toxic condition. Ironically, the infectious disease physician on duty that night was Michael Favorov, a medical virologist who went on to a productive career studying viral hepatitis, including hepatitis E, at the U.S. Centers for Disease Control and Prevention in Atlanta, Georgia. Favorov remembers not being told of the circumstances by which Balayan had acquired hepatitis, but knew from the whirl of telephone calls going on in the middle of the night that something "interesting" had transpired (M Favorov, pers. comm.)! Balayan remained in the hospital for 4 days, showing rapid improvement in his condition. After his release, he was followed medically for about a year with neither clinical nor biochemical evidence of chronic hepatitis.

Serum collected from Balayan at the time of his illness showed no IgM anti-HAV nor any increase in anti-HAV antibody titer, confirming the absence of HAV infection. Using immune electron microscopy (IEM), a method pioneered by June Almeida and used by Feinstone and colleagues to identify the HAV particle (Almeida and Waterson 1969; Feinstone et al. 1973), Balayan and colleagues identified novel 27-30 nm diameter virus-like particles in fecal samples collected between 28 and 45 days after his ingestion of the inoculum (Fig. 3) (Balayan et al. 1983). These particles banded predominantly at a density of $1.35 \mathrm{gm} / \mathrm{cm}^{3}$ in cesium chloride gradients, and reacted with antibodies present in convalescent sera from the ET-NANB patients he had studied (Balayan et al. 1983). Similar particles were subsequently identified in the fecal samples used to generate the infectious inoculum (Fig. 4).

Two cynomolgus macaque monkeys were inoculated intravenously with an extract of feces collected from Balayan 42 days after he had ingested the inoculum, when fecal virus shedding was most evident by IEM (Balayan et al. 1983). Both animals developed histologic and biochemical evidence of hepatitis, with serum ALT levels rising to 200-300 IU/L. Virus particles were shed in feces between 9 and 21 days postinoculation, and both animals developed antibodies reactive with the virus particles.

Balayan's intentional infection of himself with HEV engendered some controversy when details of the experiment were eventually reported. However, in one landmark study (Balayan

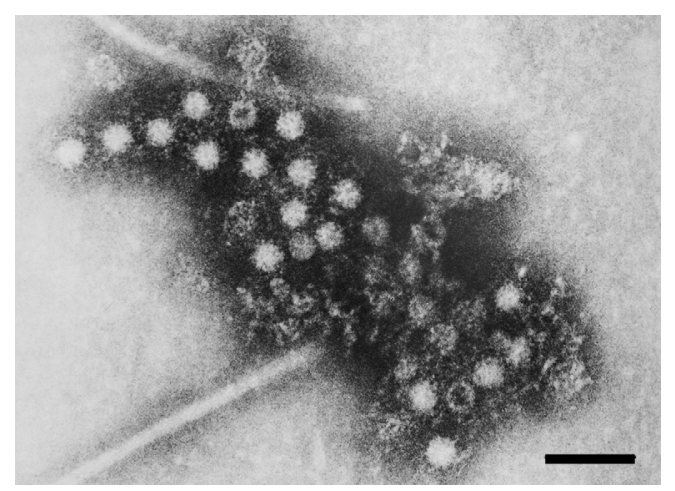

Figure 3. Immune electron microscopic image of hepatitis E virus (HEV) particles identified by Mikhail Balayan in his stool approximately 5 weeks after ingesting infectious material from patients with ETNANB hepatitis. Scale bar, $100 \mathrm{~nm}$. (From Balayan et al. 1983; adapted, with permission, from S. Karger AG ( 1 1983.) 


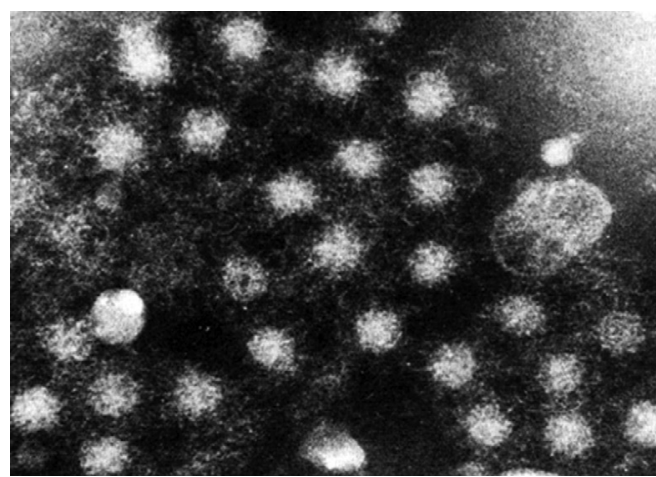

Figure 4. Immune electron microscopic image of virus particles present in one of the fecal extracts used to prepare the inoculum for Balayan's experiment. (Image provided by M. Mikhailov.)

et al. 1983), he had identified HEV, the causative agent of ET-NANB, and had developed both useful serologic tools and an animal model that would go on to be widely exploited in future studies of hepatitis E.

Surprisingly, Balayan's potentially dangerous self-experiment is not unique in the annals of hepatitis E. In 1990, almost a decade later, Ashok Chauhan, working in the Post Graduate Institute of Medical Education and Research at Chandigarh, repeated the experiment, ingesting an extract of feces from a patient involved in an outbreak of hepatitis E in Yamuna Nagar, in north India (Chauhan et al. 1993). He experienced a relatively mild illness, albeit with jaundice and low-level but prolonged serum ALT elevations up to $130 \mathrm{IU} / \mathrm{L}$. It is not clear what was hoped to be learned by this second human experiment (Chauhan et al. 1993). The course of the infection, including fecal shedding of virus and the presence of virus in blood, followed the pattern that had been worked out by then in nonhuman primate animal models (see Lanford et al. 2018).

\section{MOLECULAR CLONING OF THE HEV GENOME}

Balayan's discovery of HEV particles in feces from infected humans and cynomolgus monkeys was confirmed by other investigators in the years that followed. Antigenically related vi- ruses were recovered from multiple regions around the world, including Uzbekistan, Burma (Myanmar), Nepal, Mexico, Somalia, and Sudan (Arankalle et al. 1988; Bradley et al. 1988). However, there was controversy regarding the size (27 nm vs. $32-34 \mathrm{~nm}$ ) and number of particle types associated with ET-NANB (Bradley and Balayan 1988; Bradley 1990). The morphology of the particles was considered to be reminiscent of caliciviruses, which were known to be enteric pathogens. However, the HEV particles were relatively labile and much less stable than HAV virions, and because they were present only in relatively small numbers in fecal samples, it was difficult to characterize their nucleic acid complement. A breakthrough came in 1990 from the collaborative efforts of Gregory R. Reyes, at the biotech company Genelabs in Redwood City, CA, and Daniel W. Bradley, at the U.S. Centers for Disease Control in Atlanta, GA. Assuming that HEV was likely to be an RNA virus, these investigators prepared a complementary DNA (cDNA) library from nucleic acid extracted from bile of a cynomolgus monkey infected with a Burmese strain of HEV (Reyes et al. 1990). The use of bile provided an advantage over fecal extracts as a source of virus, as it contained large numbers of 32-34 nm virus-like particles. Using differential hybridization, a molecular clone was identified that hybridized specifically with cDNA prepared from infected but not uninfected cynomolgus bile (Reyes et al. 1990). Consistent with a viral origin, the translated amino acid sequence of this clone showed distant relatedness to RNA-dependent RNA polymerases (RdRp) encoded by a number of positive-strand RNA viruses (Reyes et al. 1990). Additional experiments identified related RNA sequences in fecal samples from ET-NANB patients in Borneo, Tashkent, Pakistan, and Somalia, suggesting worldwide distribution of a single ET-NANB agent.

Molecular cloning and sequencing of the entire $7.2 \mathrm{~kb}$ positive-strand RNA genome of the Burma strain of HEV was completed shortly thereafter by the Genelabs group (Tam et al. 1991). The genome was shown to be polyadenylated, and to contain a large $5^{\prime} 5052$ nucleotide (nt)-long open reading frame (ORF) and a 
smaller 3' 1980-nt ORF, encoding nonstructural and capsid proteins, respectively, as well as a short, overlapping 369-nt ORF (see Kenney and Meng 2018). An HEV strain from Mexico was found to have a similar genome structure (Tam et al. 1991; Huang et al. 1992), and expression cloning indicated that the Mexican virus was related antigenically to HEV from Burma (Yarbough et al. 1991). Computer-assisted analysis of the HEV sequence identified putative helicase and cysteine protease domains, as well as the $\mathrm{RdRp}$ domain, in the protein product encoded by the largest, most $5^{\prime}$ ORF (Koonin et al. 1992). The virus was shown to be related phylogenetically to rubella virus and the alphavirus supergroup, firmly distinguishing it from caliciviruses. Thus, by 1992, a decade after discovery of the ET-NANB particle by Balayan et al. (1983) and a dozen years after Khuroo's description of the epidemic in Kashmir (Khuroo 1980b), HEV was firmly established within the panoply of human hepatitis viruses.

Reverse molecular genetics studies of HEV genome function became possible with the development of the first infectious molecular clones of the HEV genome (Panda et al. 2000; Emerson et al. 2001). Transfection of RNA transcribed from these genome-length gt1 HEV cDNA clones resulted in the expression of HEV proteins in human hepatocyte-derived HepG2 or Huh-7 cell lines. Transcripts with a $5^{\prime}-\mathrm{m}^{7} \mathrm{G}$ cap were also infectious when inoculated directly into the livers of nonhuman primates (Emerson et al. 2001). An infectious molecular clone of the gt 3 swine HEV (see below) was also developed, and shown to be infectious when RNA transcribed from it was transfected into human cells or inoculated into the livers of pigs (Huang et al. 2005). Cell culture propagation of the virus remained difficult, however, and could only be achieved with particular HEV variants (Okamoto 2011; Shukla et al. 2012).

\section{GENETIC DIVERSITY OF HEV}

HEV strains from Burma, Pakistan, and Mexico were the first three viruses to be molecularly cloned and to have their full- or nearly fulllength nucleotide sequences characterized
(Tam et al. 1991; Huang et al. 1992; Tsarev et al. 1992). The Burma (BUR-121) and Pakistan (SAR-55) strains were found to be closely related, with $93.3 \%$ nucleotide identity overall, and 99.4\% amino acid sequence identity within ORF2, which encodes the capsid protein (Tsarev et al. 1992). The Mexican strain, however, was quite different. The nucleotide sequence of its genome shared only $76 \%$ identity overall with the Burma strain, whereas the amino acid sequences of ORF2 were 93\% identical (Huang et al. 1992). Subsequent phylogenetic analyses of a large number of HEV sequences recovered from sites around the world led to the Burma and Pakistan viruses being classified as members of a single genotype, gt1 HEV, whereas the Mexican strain was classified within gt2 (Lu et al. 2006). Most epidemic or sporadic cases of hepatitis $\mathrm{E}$ in endemic regions of the world have since been found to be caused by gt $1 \mathrm{HEV}$ infection, whereas very few gt 2 strains have been identified (see Smith and Simmonds 2018 for a more detailed discussion of HEV genotypes).

In 1990, Balayan and coworkers reported the transmission of human HEV to young domestic pigs inoculated intravenously with a fecal extract (Balayan et al. 1990). Infection was associated with icterus, an 11-fold increase in serum ALT, and shedding of HEV particles in feces. This was a remarkable finding at the time, as no other human hepatitis virus, including HAV, HBV, or $\mathrm{HCV}$, had been shown to infect any animal species other than nonhuman primates. ${ }^{3}$ Antibody to HEV was subsequently detected in 18 of 55 domestic swine in the Katmandu valley of Nepal, where ET-NANB hepatitis accounted for most cases of hepatitis (Clayson et al. 1995). Several animals were found to be viremic or shedding virus in feces using a reverse-transcription, polymerase chain reaction (RT-PCR) assay. These observations raised the possibility that human infections with HEV might be zoonotic in origin (Clayson et al. 1995).

The genetic and biologic diversity of HEV was expanded subsequently by studies per-

${ }^{3} \mathrm{HAV}$ has only recently been recognized to be an exception to this rule, as it can infect mice with genetic deficiencies in the type I interferon response (Hirai-Yuki et al. 2016). 
formed by Xiang J. Meng, working with Robert H. Purcell and Suzanne U. Emerson at the National Institutes of Health (Meng et al. 1997). Using a carefully validated enzyme-linked immunosorbent assay (ELISA), most swine greater than 3 months of age in commercial herds in the U.S. Midwest were found to have antibodies reactive with HEV capsid antigen, whereas swine less than 2 months of age and animals in a specific pathogen-free herd were seronegative. This was surprising, given that very few cases of hepatitis E had been identified within the United States previous to this, almost all of which affected international travelers returning from HEVendemic regions (Centers for Disease Control and Prevention 1993).

Using degenerate PCR primers based on the human HEV ORF2 sequence, Meng and colleagues (1997) were able to amplify cDNA sequences of a novel swine virus from the sera of piglets undergoing seroconversion in the ELISA assay. Equally distant genetically from the gt1 Burma and gt 2 Mexican viruses, the swine virus was distinct from human HEV strains and considered to represent a third genotype. Piglets infected with the swine virus had no outward signs of disease, but histologic examination of the liver revealed mild-to-moderate lymphocytic portal infiltrates with focal hepatocellular necrosis (Meng et al. 1997). Interstitial nephritis and enteritis were also noted in some piglets. Shortly after the discovery of gt $3 \mathrm{HEV}$ in swine, infections with closely related viruses were identified in two patients with acute hepatitis, one of whom had not traveled outside the United States (Meng et al. 1998; Schlauder et al. 1998). Virus from one of the patients was shown to infect pigs, and the swine virus was shown to replicate in both rhesus macaques (Macaca mulatta) and chimpanzees (Pan troglodytes), providing evidence for possible cross-species transmission of the virus (Meng et al. 1998). Infection was accompanied by low-level ALT elevations and minimal hepatic necroinflammatory changes in two rhesus monkeys, but was without evidence of disease in a chimpanzee. Retrospective analysis of the virus recovered from Balayan's experimentally infected pigs (Balayan et al. 1990) (see above) suggest that the disease in these animals did not result from the human virus inoculum (which was likely gt $1 \mathrm{HEV}$ ), but rather from gt3 HEV that was enzootic in the animals (Lu et al. 2004). Whether gt1 strains of $\mathrm{HEV}$ recovered from humans can infect pigs remains uncertain.

An intriguing question is whether the frequent presence of gt 3 virus in commercial American swine herds is in any way related to the unexpectedly high prevalence of anti-HEV antibodies (14\%-30\%) found among blood donors in three major urban regions of the United States (Thomas et al. 1997). Seropositive individuals in this survey did not have a more frequent history of hepatitis than those who were seronegative. The prevalence of anti-HEV antibodies was not increased in injection drug users or homosexual males, in whom both HAV and $\mathrm{HBV}$ antibodies were more prevalent than in blood donors (Thomas et al. 1997).

There is other evidence for cases of autochthonously acquired hepatitis E within the United States. A laboratory-based survey of $\mathrm{HEV}$ infections in the United States identified 26 cases of serologically or virologically confirmed hepatitis E between 2005 and 2012 (Drobeniuc et al. 2013). Fifteen of these 26 patients had no history of recent travel outside the United States, and eight of these 15, in whom the genotype of the virus could be determined, were infected with gt 3 virus. The close relatedness of these viruses to viruses circulating in commercial swineherds in the United States (Fig. 5) suggests the possibility that these infections may have had a zoonotic origin (Drobeniuc et al. 2013). Direct evidence for this remains weak, but HEV RNA was detected by RT-PCR in $11 \%$ of pig livers purchased from grocery stores in Ames, IA, and Blacksburg, VA, in the United States during 2005-2006; some of these livers were shown to contain viable gt 3 virus capable of infecting pigs (Feagins et al. 2007).

Of four U.S. travelers who had developed hepatitis E in the United States after returning from abroad between 2005 and 2012, three had visited India and were infected with gt1 virus (Drobeniuc et al. 2013). The fourth had visited China, and was infected with gt $4 \mathrm{HEV}$, yet a fourth genotype was first identified in patients 
S.M. Lemon and C.M. Walker

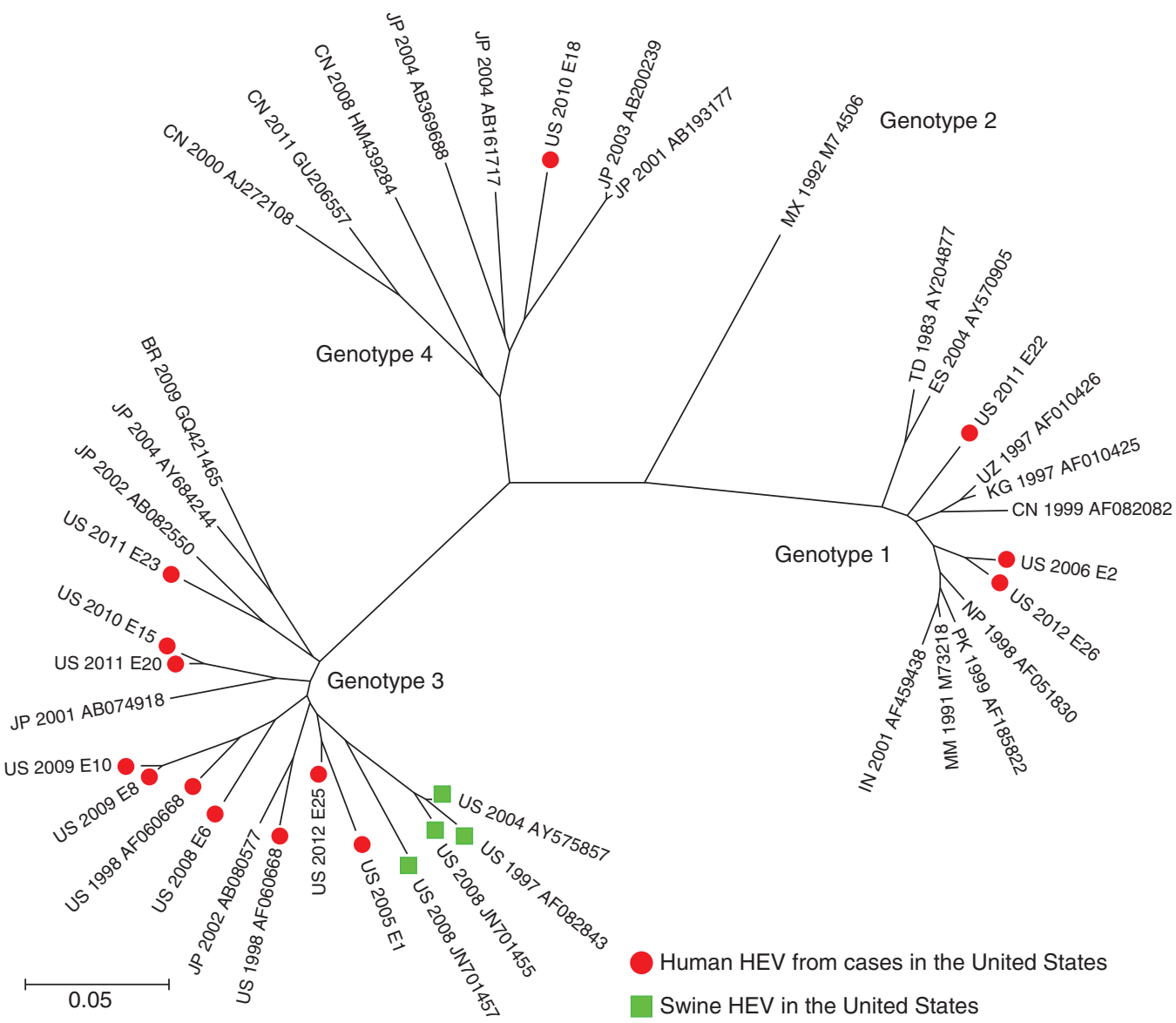

Figure 5. Genetic relatedness of hepatitis E virus (HEV) strains identified in U.S. residents with either autochthonously acquired genotype (gt)3 or travel-associated (gtl and gt4) hepatitis E. The phylogenetic tree was generated using the neighbor-joining method, and includes gt3 swine HEV sequences and representative sequences of each of the four major Orthohepesvirus A genotypes. (From Drobeniuc et al. 2013; adapted courtesy of Public Domain material provided by the journal Emerging Infectious Diseases.)

with acute hepatitis in Taiwan and China (Hsieh et al. 1998; Wang et al. 1999). Like gt3 virus, gt4 $\mathrm{HEV}$ has been shown to infect domestic swine (Hsieh et al. 1999). Human infection with a fifth, camelid-associated HEV genotype (gt7) also has been reported recently (Lee et al. 2016), and it would not be surprising to find additional, genetically diverse viruses infecting humans in the future. The Hepeviridae are now known to be a large and diverse family of viruses with two genera, one of which (Orthohepesvirus) includes four distinct species infecting a wide variety of mammalian and avian species. The five HEV genotypes recovered from humans thus far are all assigned to a single one of these species, Orthohepevirus A, which includes, in addition, two to three other HEV genotypes (see Smith and Simmons 2018).

\section{HEV PERSISTENCE AND CHRONIC LIVER DISEASE}

The coda to this history of HEV is the finding of persistent infections associated with progressive liver disease approximately a decade ago. Whereas the specificity of serological assays for antibodies to HEV has been questioned in the past, there is now a generally broad consen- 
sus that substantial minorities of both North American and European populations have antibodies reactive with $\mathrm{HEV}$ antigen (reviewed by Dalton et al. 2008). Similar to the $21 \%$ prevalence of anti-HEV antibodies in blood donors in Baltimore, MD (Thomas et al. 1997), surveys in the Catalonia region of Spain, the southwest of England, the southwest of France, and Germany have revealed population prevalences of anti-HEV IgG ranging from $8 \%$ to $16 \%$ (Dalton et al. 2008; Faber et al. 2012). Most seropositive individuals lack a history of hepatitis, and are likely to have been infected asymptomatically with gt3 HEV (or an unknown, antigenically related virus) sometime in the past. Thus, although the source of virus and mechanisms of transmission remain ill-defined, increasing evidence suggests that HEV infections are relatively common in well-developed countries in which symptomatic hepatitis $\mathrm{E}$ infections are rare (Aspinall et al. 2017).

These infections appear to be well controlled by the immune system, although much remains to be learned concerning the details of immune control of HEV. However, persons with compromised immunity are at risk for persistent $\mathrm{HEV}$ infection leading to progressive liver disease. This was first recognized among liver and kidney transplant recipients with compromised immune systems in Toulouse, France in 2008 (Kamar et al. 2008). Eight of 14 transplant recipients with acute HEV infection failed to clear the virus, remaining persistently viremic or with viral RNA detectable in feces for 10-24 months. Liver biopsies performed 10-18 months after acute infection showed chronic hepatitis with dense lymphocytic portal infiltrates, piecemeal necrosis, and fibrosis with increasing Metavir scores (Kamar et al. 2008). Patients with a wide variety of immunodeficiencies, including those with hematological malignancies and human immunodeficiency, have since been shown to be at risk for chronic HEV infection that can progress to cirrhosis (Kamar et al. 2011, 2013). Ingestion of undercooked pork has been implicated in the acquisition of these HEV infections. In addition to gt $3 \mathrm{HEV}$, chronic infection has recently been documented with camelid-associated gt7 HEV in an immunocompromised individual (Lee et al. 2016).

\section{CONCLUDING REMARKS}

No longer a virus causing only epidemic and sporadic non-A, non-B hepatitis in underdeveloped regions of the world, $\mathrm{HEV}$ is emerging as a significant pathogen in economically advanced nations as well. It is unlikely that this emergence reflects an increase in $\mathrm{HEV}$ infections, as antiHEV seroprevalence actually appears to have declined in the United States in recent years (Teshale et al. 2015). The emergence of HEV is much more likely to represent an increased appreciation for infections that previously went unnoticed or were considered caused by HAV. This change in awareness can be attributed largely to improved diagnostics, including both serological assays and methods for detecting viral RNA. However, Food and Drug Administration (FDA)-approved diagnostic tests for $\mathrm{HEV}$ remain lacking in the United States, and we can expect our appreciation of the diversity of clinical manifestations and impact of $\mathrm{HEV}$ infection to continue to broaden as such tests enter routine clinical practice.

Despite recent advances, many critical questions remain. Efficacious recombinant $\mathrm{HEV}$ vaccines have been developed (see Innis and Lynch 2018), but immune correlates of protection remain ill-defined, as does the ability of these vaccines to protect patients with compromised immune systems. Pathogenesis is also poorly understood. HEV gt1 and gt 3 share numerous features in common, including relatively close sequence relatedness, yet they are dramatically different in terms of their ability to cause human disease, including particularly severe disease in pregnant women. The epidemiology of these genotypes and, in particular, the extent of zoonotic transmission are also poorly understood. Is there an animal reservoir for gt 1 and gt2 HEV? Are gt3 HEV infections zoonotic in nature and, if so, what is the linkage that explains such high seroprevalence in the United States and Europe? Much has been learned about HEV over the past few decades, but much remains to be discovered. 
S.M. Lemon and C.M. Walker

\section{ACKNOWLEDGMENTS}

The authors gratefully acknowledge information and materials provided by Professor Mohammed S. Khuroo of the Digestive Diseases Centre, Srinagar, Kashmir, India, Professor Mikhail Mikhailov of the Mechnikov Research Institute for Vaccines and Sera, Moscow, Russia, Dr. Alexander Anjaparidze, formerly of the World Health Organization, Dr. Michael Favorov of the International Vaccine Institute, and Dr. Konstantin Chumakov of the U.S. Food and Drug Administration. We thank Drs. Robert Purcell and Suzanne Emerson for their critical review of an earlier draft of this manuscript.

\section{REFERENCES}

${ }^{*}$ Reference is also in this collection.

Almeida JD, Waterson AP. 1969. The morphology of virusantibody interaction. Adv Vir Res 15: 307-338.

Andjaparidze A. 2010. The history of hepatitis E discovery (abstract). International Symposium on Hepatitis E. Seoul, South Korea.

Anonymous. 1863. Progress in medical science: Icterus in pregnant women. $\mathrm{Br} \mathrm{Med} J$ 1: 141.

Arankalle VA, Ticehurst J, Sreenivasan MA, Kapikian AZ Popper H, Pavri KM, Purcell RH. 1988. Aetiological association of a virus-like particle with enterically transmitted non-A, non-B hepatitis. Lancet 331: 550-554.

Aspinall EJ, Couturier E, Faber M, Said B, Ijaz S, Tavoschi L, Takkinen J, Adlhoch C. 2017. Hepatitis E virus infection in Europe: Surveillance and descriptive epidemiology of confirmed cases, 2005 to 2015. Euro Surveill 22: 30561.

Balayan MS, Andjaparidze AG, Savinskaya SS, Ketiladze ES, Braginsky DM, Savinov AP, Poleschuk VF. 1983. Evidence for a virus in non-A, non-B hepatitis transmitted via the fecal-oral route. Intervirology 20: 23-31.

Balayan MS, Usmanov RK, Zamyathina NA, Djumalieva DI, Karas FR. 1990. Brief report: Experimental hepatitis E infection in domestic pigs. J Med Virol 32: 58-59.

Bendall R, Ellis V, Ijaz S, Ali R, Dalton H. 2010. A comparison of two commercially available anti-HEV IgG kits and a re-evaluation of anti-HEV IgG seroprevalence data in developed countries. J Med Virol 82: 799-805.

Blumberg BS, Alter HJ, Visnich S. 1965. A “new” antigen in leukemia sera. JAMA 191: 541-546.

Bradley DW. 1990. Enterically-transmitted non-A, non-B hepatitis. British Med Bull 46: 442-461.

Bradley DW, Balayan MS. 1988. Virus of enterically transmitted non-A, non-B hepatitis. Lancet 1: 819.

Bradley D, Andjaparidze A, Cook EH Jr, McCaustland K, Balayan M, Stetler H, Velazquez O, Robertson B, Humphrey C, Kane M, et al. 1988. Aetiological agent of enteri- cally transmitted non-A, non-B hepatitis. J Gen Virol 69: 731-738.

Centers for Disease Control and Prevention. 1993. Hepatitis E among U.S. travelers, 1989-1992. MMWR 42: 1-4.

Chauhan A, Jameel S, Dilawari JB, Chawla YK, Kaur U, Ganguly NK. 1993. Hepatitis E virus transmission to a volunteer. Lancet 341: 149-150.

Clayson ET, Myint KSA, Snitbhan R, Vaughn DW, Innis BL, Chan L, Cheung P, Shrestha MP. 1995. Viremia, fecal shedding, and IgM and IgG responses in patients with hepatitis E. J Infect Dis 172: 927-933.

Dalton HR, Bendall R, Ijaz S, Banks M. 2008. Hepatitis E: An emerging infection in developed countries. Lancet Infect Dis 8: 698-709.

Drobeniuc J, Greene-Montfort T, Le NT, Mixson-Hayden TR, Ganova-Raeva L, Dong C, Novak RT, Sharapov UM, Tohme RA, Teshale E, et al. 2013. Laboratory-based surveillance for hepatitis E virus infection, United States, 2005-2012. Emerg Infect Dis 19: 218-222.

Emerson SU, Zhang M, Meng XJ, Nguyen H, St Claire M, Govindarajan S, Huang YK, Purcell RH. 2001. Recombinant hepatitis $\mathrm{E}$ virus genomes infectious for primates: Importance of capping and discovery of a cis-reactive element. Proc Natl Acad Sci 98: 15270-15275.

Faber MS, Wenzel JJ, Jilg W, Thamm M, Hohle M, Stark K. 2012. Hepatitis E virus seroprevalence among adults, Germany. Emerg Infect Dis 18: 1654-1657.

Feagins AR, Opriessnig T, Guenette DK, Halbur PG, Meng XJ. 2007. Hepatitis E virus from commercial pig livers sold in local grocery stores in the USA. J Gen Virol 88: 912-917.

* Feinstone SM. 2018. History of the discovery of hepatitis A virus. Cold Spring Harb Perspect Med doi: 10.1101/ cshperspect.a031740.

Feinstone SM, Kapikian AZ, Purcell RH. 1973. Hepatitis A: Detection by immune electron microscopy of a viruslike antigen associated with acute illness. Science 182: 10261028.

Feinstone SM, Kapikian AZ, Purcell RH, Alter HJ, Holland PV. 1975. Transfusion-associated hepatitis not due to viral hepatitis type A or B. N Engl J Med 292: 767-770.

Grau LW, Jorgensen WA. 1995. Medical support in a counter-guerilla war: Epidemiologic lessons learned in the Soviet-Afghan war. US Army Med Dep J 41-49.

Gupta DN, Smetana HF. 1955. The histopathology of viral hepatitis as seen in Delhi epidemic. Indian J Med Res 45: 101-113.

Hirai-Yuki A, Hensley L, McGivern DR, Gonzalez-Lopez O, Das A, Feng H, Sun L, Wilson JE, Hu F, Feng Z, et al. 2016. MAVS-dependent host species range and pathogenicity of human hepatitis A virus. Science 353: 1541-1545.

Hsieh SY, Yang PY, Ho YP, Chu CM, Liaw YF. 1998. Identification of a novel strain of hepatitis $\mathrm{E}$ virus responsible for sporadic acute hepatitis in Taiwan. J Med Virol 55: 300-304.

Hsieh SY, Meng XJ, Wu YH, Liu ST, Tam AW, Lin DY, Liaw YF. 1999. Identity of a novel swine hepatitis E virus in Taiwan forming a monophyletic group with Taiwan isolates of human hepatitis E virus. J Clin Microbiol 37: 3828-3834. 
Huang CC, Nguyen D, Fernandez J, Yun KY, Fry KE, Bradley DW, Tam AW, Reyes GR. 1992. Molecular cloning and sequencing of the Mexico isolate of hepatitis $\mathrm{E}$ virus (HEV). Virology 191: 550-558.

Huang YW, Haqshenas G, Kasorndorkbua C, Halbur PG, Emerson SU, Meng XJ. 2005. Capped RNA transcripts of full-length cDNA clones of swine hepatitis $\mathrm{E}$ virus are replication competent when transfected into Huh7 cells and infectious when intrahepatically inoculated into pigs. J Virol 79: 1552-1558.

* Innis BL, Lynch JA. 2018. Immunization against hepatitis E. Cold Spring Harb Perspect Med doi: 10.1101/cshperspect. a032573.

Kamar N, Selves J, Mansuy JM, Ouezzani L, Peron JM, Guitard J, Cointault O, Esposito L, Abravanel F, Danjoux M, et al. 2008. Hepatitis E virus and chronic hepatitis in organ-transplant recipients. N Engl J Med 358: 811-817.

Kamar N, Garrouste C, Haagsma EB, Garrigue V, Pischke S, Chauvet C, Dumortier J, Cannesson A, Cassuto-Viguier E, Thervet E, et al. 2011. Factors associated with chronic hepatitis in patients with hepatitis $\mathrm{E}$ virus infection who have received solid organ transplants. Gastroenterology 140: 1481-1489.

Kamar N, Rostaing L, Izopet J. 2013. Hepatitis E virus infection in immunosuppressed patients: Natural history and therapy. Sem Liver Dis 33: 62-70.

* Kenney SP, Meng X-J. 2018. Hepatitis E virus genome structure and replication strategy. Cold Spring Harb Perspect Med doi: $10.1101 /$ cshperspect.a031724.

Khuroo MS. 1980a. Chronic liver disease after non-A, non-B hepatitis. Lancet 2: 860-861.

Khuroo MS. 1980b. Study of an epidemic of non-A, non-B hepatitis: Possibility of another human hepatitis virus distinct from post-transfusion non-A, non-B type. Am J Med 68: $818-824$.

Khuroo MS. 2011. Discovery of hepatitis E: The epidemic non-A, non-B hepatitis 30 years down the memory lane. Virus Res 161: 3-14.

Khuroo MS, Teli MR, Skidmore S, Sofi MA, Khuroo MI. 1981. Incidence and severity of viral hepatitis in pregnancy. Am J Med 70: 252-255.

Koonin EV, Gorbalenya AE, Purdy MA, Rozanov MN, Reyes GR, Bradley DW. 1992. Computer-assisted assignment of functional domains in the nonstructural polyprotein of hepatitis E virus: Delineation of an additional group of positive-strand RNA plant and animal viruses. Proc Natl Acad Sci 89: 8259-8263.

* Lanford RE, Walker CM, Lemon SM. 2018. Nonhuman primate models of hepatitis A virus and hepatitis $\mathrm{E}$ virus infections. Cold Spring Harb Perspect Med doi: 10.1101/ cshperspect.a031815.

Lee GH, Tan BH, Teo EC, Lim SG, Dan YY, Wee A, Aw PP, Zhu Y, Hibberd ML, Tan CK, et al. 2016. Chronic infection with camelid hepatitis E virus in a liver transplant recipient who regularly consumes camel meat and milk. Gastroenterology 150: 355-357.e353.

Lu L, Drobeniuc J, Kobylnikov N, Usmanov RK, Robertson BH, Favorov MO, Margolis HS. 2004. Complete sequence of a Kyrgyzstan swine hepatitis E virus (HEV) isolated from a piglet thought to be experimentally infected with human HEV. J Med Virol 74: 556-562.
Lu L, Li C, Hagedorn CH. 2006. Phylogenetic analysis of global hepatitis E virus sequences: Genetic diversity, subtypes and zoonosis. Rev Med Virol 16: 5-36.

Meng XJ, Purcell RH, Halbur PG, Lehman JR, Webb DM, Tsareva TS, Haynes JS, Thacker BJ, Emerson SU. 1997. A novel virus in swine is closely related to the human hepatitis E virus. Proc Natl Acad Sci 94: 9860-9865.

Meng XJ, Halbur PG, Shapiro MS, Govindarajan S, Bruna JD, Mushahwar IK, Purcell RH, Emerson SU. 1998. Genetic and experimental evidence for cross-species infection by swine hepatitis E virus. J Virol 72: 9714-9721.

Mosley JW, Redeker AG, Feinstone SM, Purcell RH. 1977. Multiple hepatitis viruses in multiple attacks of acute viral hepatitis. N Engl J Med 296: 75-78.

Okamoto H. 2011. Efficient cell culture systems for hepatitis E virus strains in feces and circulating blood. Rev Med Virol 21: 18-31.

Panda SK, Ansari IH, Durgapal H, Agrawal S, Jameel S. 2000. The in vitro-synthesized RNA from a cDNA clone of hepatitis E virus is infectious. J Virol 74: 2430-2437.

Perepelkin VS, Korol'kov VF, Kolkov VF, Mandrik VA, Ogarkov PI. 1991. The lessons of the fight against intestinal infections during the war in Afghanistan. Voen Med Zh 7: 27-31.

Pischke S, Hartl J, Pas SD, Lohse AW, Jacobs BC, Van der Eijk AA. 2017. Hepatitis E virus: Infection beyond the liver? J Hepatol 66: 1082-1095.

Prikazchikov SA, Balayan MS. 1987. Shifts in the rates and levels of antibody to hepatitis A virus associated with hepatitis A infection in children's communities. European J Epidemiol 3: 370-376.

Prince AM. 1968. An antigen detected in the blood during the incubation period of serum hepatitis. Proc Natl Acad Sci 60: 814-821.

Reyes GR, Purdy MA, Kim JP, Luk KC, Young LM, Fry KE, Bradley DW. 1990. Isolation of a cDNA from the virus responsible for enterically transmitted non-A, non-B hepatitis. Science 247: 1335-1339.

Schlauder GG, Dawson GJ, Erker JC, Kwo PY, Knigge MF, Smalley DL, Rosenblatt JE, Desai SM, Mushahwar IK. 1998. The sequence and phylogenetic analysis of a novel hepatitis $\mathrm{E}$ virus isolated from a patient with acute hepatitis reported in the United States. J Gen Virol 79: 447456.

Shukla P, Nguyen HT, Faulk K, Mather K, Torian U, Engle RE, Emerson SU. 2012. Adaptation of a genotype 3 hepatitis $\mathrm{E}$ virus to efficient growth in cell culture depends on an inserted human gene segment acquired by recombination. J Virol 86: 5697-5707.

* Smith DB, Simmonds P. 2018. Classification and genomic diversity of enterically transmitted hepatitis viruses. Cold Spring Harb Perspect Med doi: 10.1101/cshperspect. a 031880 .

Tam AW, Smith MM, Guerra ME, Huang CC, Bradley DW, Fry KE, Reyes GR. 1991. Hepatitis E virus (HEV): Molecular cloning and sequencing of the full-length viral genome. Virology 185: 120-131.

Tandon BN, Gandhi BM, Joshi YK, Irshad M, Gupta H. 1985. Hepatitis virus non-A, non-B: The cause of a major public health problem in India. Bull World Health Org 63: 931-934. 
S.M. Lemon and C.M. Walker

Teshale EH, Denniston MM, Drobeniuc J, Kamili S, Teo CG, Holmberg SD. 2015. Decline in hepatitis E virus antibody prevalence in the United States from 1988-1994 to 20092010. J Infect Dis 211: 366-373.

Thomas DL, Yarbough PO, Vlahov D, Tsarev SA, Nelson KE, Saah AJ, Purcell RH. 1997. Seroreactivity to hepatitis E virus in areas where the disease is not endemic. J Clin Microbiol 35: 1244-1247.

Tsarev SA, Emerson SU, Reyes GR, Tsareva TS, Legters LJ, Malik IA, Iqbal M, Purcell RH. 1992. Characterization of a prototype strain of hepatitis E virus. Proc Natl Acad Sci 89: 559-563.

Villarejos VM, Visona KA, Eduarte CA, Provost PJ, Hilleman MR. 1975. Evidence for viral hepatitis other than type A or type B among persons in Costa Rica. N Engl J Med 293: 1350-1352.

Wang Y, Ling R, Erker JC, Zhang H, Li H, Desai S, Mushahwar IK, Harrison TJ. 1999. A divergent genotype of hepatitis $\mathrm{E}$ virus in Chinese patients with acute hepatitis. J Gen Virol 80: 169-177.

Wong DC, Purcell RH, Sreenivasan MA, Prasad SR, Pavri KM. 1980. Epidemic and endemic hepatitis A in India: evidence for a non-A, non-B hepatitis virus etiology. Lancet 2: 876-879.

Yarbough PO, Tam AW, Fry KE, Krawczynski K, McCaustland KA, Bradley DW, Reyes GR. 1991. Hepatitis E virus: Identification of type-common epitopes. J Virol 65: 5790-5797. 


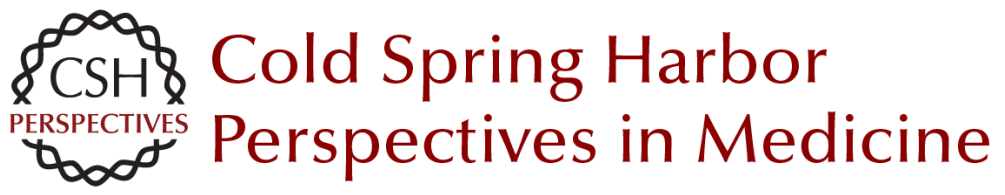

\section{Enterically Transmitted Non-A, Non-B Hepatitis and the Discovery of Hepatitis E Virus}

Stanley M. Lemon and Christopher M. Walker

Cold Spring Harb Perspect Med 2019; doi: 10.1101/cshperspect.a033449 originally published online May 7, 2018

Subject Collection Enteric Hepatitis Viruses

Hepatitis A Virus Genome Organization and

Replication Strategy

Kevin L. McKnight and Stanley M. Lemon

Adaptive Immune Responses in Hepatitis A Virus and Hepatitis E Virus Infections Christopher M. Walker

Small Animal Models of Hepatitis E Virus Infection Tian-Cheng Li and Takaji Wakita

Acute and Persistent Hepatitis E Virus Genotype 3 and 4 Infection: Clinical Features, Pathogenesis, and Treatment

Nassim Kamar and Sven Pischke

Epidemiology of Genotype 1 and 2 Hepatitis E

Virus Infections

Kenrad E. Nelson, Alain B. Labrique and Brittany L. Kmush

History of the Discovery of Hepatitis A Virus Stephen M. Feinstone

Epidemiology and Transmission of Hepatitis A Virus and Hepatitis E Virus Infections in the United States

Megan G. Hofmeister, Monique A. Foster and Eyasu H. Teshale

Stem Cell-Derived Culture Models of Hepatitis E

Virus Infection

Viet Loan Dao Thi, Xianfang Wu and Charles M. Rice
Evolutionary Origins of Enteric Hepatitis Viruses Anna-Lena Sander, Victor Max Corman, Alexander N. Lukashev, et al.

Enterically Transmitted Non-A, Non-B Hepatitis and the Discovery of Hepatitis E Virus Stanley M. Lemon and Christopher M. Walker

Natural History, Clinical Manifestations, and

Pathogenesis of Hepatitis E Virus Genotype 1 and 2 Infections

Rakesh Aggarwal and Amit Goel

Hepatitis A Virus and Hepatitis E Virus: Emerging and Re-Emerging Enterically Transmitted

Hepatitis Viruses

Stanley M. Lemon and Christopher M. Walker

Hepatitis A Virus Capsid Structure

David I. Stuart, Jingshan Ren, Xiangxi Wang, et al.

Comparative Pathology of Hepatitis A Virus and

Hepatitis E Virus Infection John M. Cullen and Stanley M. Lemon

Innate Immunity to Enteric Hepatitis Viruses Zongdi Feng and Stanley M. Lemon

Nonhuman Primate Models of Hepatitis A Virus and Hepatitis E Virus Infections

Robert E. Lanford, Christopher M. Walker and Stanley M. Lemon

For additional articles in this collection, see http://perspectivesinmedicine.cshlp.org/cgi/collection/ 